\title{
"EL DESTINO, EL TRABAJO Y LA MUERTE". NOTAS INTERPRETATIVAS SOBRE ALGUNAS OBRAS DE MAURICE MAETERLINCK
}

\section{Por Teresa del Conde}

El presente artículo surgió de una idea concebida por los directores de la Editorial Porxúa, idea dirigida a publicar conjuntamente las Vidas de los insectos y El pájaro azul de Maurice Maeterlinck. Por razones diversas sólo se publicó una nueva traducción de esta última obra, precedida por un prólogo que, en su forma incial, había sido concebido como un escrito mucho más extenso. Dado el especial interés que existe tanto en México como en otros países por revaluar el movimiento simbolista, hemos revisado el artículo para presentarlo ahora en su versión completa.

Hay artistas y hombres de letras cuya vocación se decide merced a una circunstancia fortuita que viene a afianzarlos definitivamente en un determinado camino, hasta entonces solamente intuido o vislumbrado, o bien entrevistado con claridad, pero aún no abrazado conscientemente como la vía magna a la que confluirán inquietudes, anhelos y logros.

Maurice Maeterlinck dio señales tempranas de su disposición a las letras. Le gustaba vagar por las orillas del canal cercano al sitio donde transcurrió su infancia, mirando los árboles, el agua y las nubes, mientras su mente se entretenfa en confusas ensoñaciones que después daban lugar a sus incipientes tanteos de dramaturgo y poeta.

Un recuerdo infantil, rememorado posteriormente en el prólogo de su primer volumen de teatro, nos muestra cómo a la edad de nueve o diez años compuso y dirigió su primerá pieza teatral: un arreglo de Molière que nació de solitarias lecturas hechas al calor del fuego durante los largos meses de inviemo, en el acogedor ambiente familiar de la biblioteca de su abuela. Sin embargo, realista y disciplinado, a la par que idealista y soñador, cuando hubo que escoger profesión, se decidió por una que fuese segura y que no contrariase los intereses familiares. Estudió la carrera de derecho y, fiel representante de las virtudes burguesas de su clase, encaminó sus miras a llevar una vida discreta pero en la que no faltaran los satisfactores materiales que aprendió a apreciar desde su infancia, ni tampoco la soledad y el recogimiento necesarios para proporcionar a su espíritu todo lo que le demandaba. Por estas razones no pasó por alto la oportunidad de obtener una plaza de juez de paz en una pequeña ciudad de provincia. Pero esta discretísima aspiración se derrumbó merced a la 
incursión inesperada de un reconocimiento literario que de la noche a la mañana lo situó como brillante promesa en el panorama de las letras francesas, dentro de la corriente más en boga del momento: el simbolismo.

Además de un pequeño volumen de poesías, Maeterlinck había escrito y publicado por su cuenta, en un tiraje de cien ejemplares a la rústica, un drama entre shakespereano y simbolista que ya contiene las principales constantes que encontramos en la primera fase de su obra literaria. Se trata de La princesa Maleine, cuya trama está poblada de seres enfermizos y taciturnos, a veces malvados, que pasean sus fantasmagóricas apariencias en la oscuridad de viejos castillos rodeados de fosos y estanques en los que la pálida luz de la luna opera transformaciones extrañas. Eros y Thanatos -como en otras obras posteriores de Maeterlinck- son las fuerzas actuantes principales, que secundadas por el destino y la ignominia rigen los destinos de los personajes. La incesante intervención de fenómenos naturales - como el trueno, la lluvia, o el crujir del viento-, en todo momento subrayan el pensamiento y la acción de cada uno de los protagonistas que fatalmente corren en pos de su destino.

Es interesante señalar que ya desde ahora, la heroína de este drama, o sea la propia princesa Maleine, no está dotada de ningún atributo definido que la singularice. No es propiamente bella, puesto que ni siquiera su enamorado puede describirla con precisión. Éste sólo recuerda que tiene un modo peculiar de bajar los párpados y de cruzar las manos y que su mirada es cambiante "como un canal de agua fresca". Tampoco es posible saber si es comunicativa o reservada, apasionada o contenida, porque su creador no le da oportunidad de expresar sus sentimientos más que en la forma vaga e indeterminada con la que nos da a conocer su apariencia física a través de las rememoraciones de su amante. Esta presencia incierta, mutante y casi irreal, se mueve entre otras que son tan imprecisas o más que ella misma. Diríase que una neblina persistente desdibuja sus perfiles, a tiempo que ecos de sonidos lejanos, como el tañer de unas campanas, el tamborilleo de la lluvia sobre los cristales o la monótona entonación del Dies Irae, orquestan reiteradamente lo que viene a ocupar el lugar de la acción.

Tales presencias indefinibles, discurriendo en una ambientación que en pintura encontraría su equivalente en algunos cuadros de los prerrafaelitas ingleses, no podía menos que llamar la atención de los poetas simbolistas. Así sucedió. El volumen llegó a manos de Stephane Mallarmé, quien desde tiempo atrás era reverenciado como si fuera un pontífice, o un vidente, por aquel grupo de escritores que formaban cenáculo en torno 
suyo, semana a semana, en una casa de la calle de Rome que funcionaba casi como si fuera un templo. Mallarmé lo remitió a Octave Mirbeau, que aparte de ser por entonces uno de los más sagaces críticos parisienses, era también dramaturgo. La respuesta de éste fue inmediata. Publicó un artículo en Le Figaro, decisivo en cuanto a los alcances que tuvo, ya que atrajo sobre Maeterlinck la atención inmediata de todo el grupo simbolista. Mirbeau lo comparaba con Shakespeare, afirmando que, aun cuando no sabía absolutamente nada sobre su persona, lo que había escrito era "la obra más genial de estos tiempos, la más extraordinaria y también la más ingenua... Una obra maestra como han soñado escribirla a veces, en las horas de entusiasmo, los artistas honrados y atormentados, y como hasta ahora no han escrito ninguna."

No es éste el lugar para hacer consideraciones acerca de la validez de la crítica de Mirbeau, ni mucho menos para discutir sobre los méritos y deméritos que se conjugan en esta obra tan peculiar, semejante a algunos edificios neorománticos que son como relicarios de varias épocas y de muchos estilos arquitectónicos a la vez. Lo cierto es que el artículo convirtió a Maeterlinck, de escritor punto menos que desconocido, en figura literaria, actuando como intenso acicate en un momento particularmente propicio. Si el autor de La princesa Maleine hasta entonces podía albergar dudas acerca de sus aptitudes y, sobre todo, de la posibilidad de llegar a encontrar aceptación, ahora no había que dudar ya, pues su destino se había hecho manifiesto. Mesurado y objetivo como siempre fue, no se dejó deslumbrar por el tono panegirista del escrito, pero sí se dio perfecta cuenta de que coincidía en tendencias e intereses con la corriente literaria más importante del momento y que su verdadera carrera estaba decidida.

Todavía manteniendo ante sus allegados el subterfugio de un supuesto interés por perfeccionarse en sus estudios de leyes, partió a París con el pretexto de escuchar a los más famosos litigantes franceses. Efectivamente asistió a algunas sesiones en el Ministerio de Justicia, pero al mismo tiempo se relacionó con un grupo de poetas posparnasianos, que se reunían por las tardes en torno a Villiers de L'Isle Adam, el autor de Axel, aquel drama que tiene por héroe a un príncipe que desdeña la vida porque vivir es vulgar y que, por consiguiente, se suicida junto con su amada dando así "un salto sagrado" que simboliza la identidad del amor con la muerte. Más de medio siglo después, Maeterlinck aún hablaba con 
entusiasmo de este encuentro, que según sus propias palabras, fue decisivo para su trayectoria posterior como literato.

Maeterlinck llegó a París en 1886. Hacía diez años que Mallarmé había escrito Herodias y La siesta de un fauno, dos de las obras más representativas de la poesía simbolista, que nos remiten a las correspondencias que Baudelaire encontraba entre los sonidos, los colores, los sentimientos y las palabras. Un año antes Mallarmé había escrito otro singular poema en el que rendía homenaje a Des-Esseintes, el héroe de la novela $A u R e-$ burs de Karl J. Huysmans. Este personaje, que en su momento llegó a tener más realidad que cualquier ser vivo, había adquirido un valor autónomo no ya como creación literaria, sino como prototipo del estético fatigado, cuyo refinamiento llevado a ultranza, personifica idealmente el ennui decadentista. Verlaine ya había publicado en 1883 sus Poetas malditos, en tanto que ese mismo año de 1886 aparecían las Illuminations de Rimbaud, escritas casi diez y seis años antes.

Decadentismo y simbolismo no son términos sinónimos, aunque tienden a usarse indistintamente. Hay muchas formas de decadentismo, pero tres son particularmente típicas: la que cerró el mundo pagano durante los primeros siglos de nuestra era; la representada por la producción tanto artística como literaria de la corriente manierista, principalmente tal y como se da en Italia durante el siglo xvi y la que, a fines del siglo pasado, clausura un ciclo iniciado por el Romanticismo. El espíritu "decadente" tiende a replegarse sobre sí mismo y a considerar los resultados perseguidos por una determinada forma de civilización como realidades definitivamente conquistadas, pero susceptibles de un refinamiento preciosista que puede llegar hasta el absurdo. El decadentismo finisecular es una condición inherente al mal du siècle, "mal" no sólo significa lo opuesto a bien, sino también enfermedad, que se manifiesta en todas las ramas de la actividad humana, pero que además de eso, es paradojicamente una actitud vital.

La palabra "simbolismo", tan afortunada como imprecisa, apareció por primera vez designando a una corriente literaria en 1885, cuando ya existía desde años atrás un grupo formado en torno a Verlaine, por los disidentes del Parnasianismo, a quienes sus adversarios, en son de burla, llamaron "decadentes". El simbolismo viene a ser, tanto en literatura como en las artes plásticas, una manifestación del espíritu decadente que trasmina una exagerada necesidad de espiritualización. Los simbolistas espiritualizar on las sensaciones, manejando las palabras como símbolos de correspondencia entre el espíritu y las cosas. La realidad literaria (o 
pictórica en su caso), es reflejo de la realidad permanente del universo, que la poesía expresa a través de sugerencias y alusiones enraizadas en el sueño, el misterio y la indefinición. Tanto la pintura y la poesía, como la prosa o el drama simbolista, rehúyen, diriase que con horror, todo aquello que pudiera presentarse revestido de certeza. Repudian en forma drástica lo categórico, lo descriptivo y lo didáctico, y en cambio ofrecen franca apertura a todo lo que es equívoco, ambiguo, oculto o indefinido. Las imágenes simbolistas son incompletas por necesidad, ya que si no lo fueran, perderían su razón de ser, que consiste en buscar su plenitud a través de las asociaciones en cadena que provocan. Así por ejemplo, el concepto belleza, tal y como aparecería relacionado con los atributos de una mujer, jamás es expresado a través de una descripción, sino, si se quiere, a partir de negaciones. En Aglavena y Seliseta de Maeterlinck, cuando Meleandro habla de la belleza de Aglavena, dice que es como "otra belleza y nada más... una belleza que deja paso al alma sin interrumpirla nunca ..." La Beata Beatrix de Dante Gabriel Rossetti es bella principalmente porque representa la imagen de un ser ya muerto. A la vez es "Beata" debido a que a través del láudano, representado en la pintura mediante una flor, el cuerpo material trascendió voluntariamente su condición, pasando a un estado superior de existencia. Esta imagen, cuyo modelo póstumo fue una joven suicida, se convirtió en objeto de reverencia por parte de un gran número de poetas y pintores.

Desde luego que el simbolismo abreva en fuentes muy diversas, algunas de ellas bastante lejanas, pero todas en cierta manera relacionadas entre sí. En esta corriente vienen a confluir varias de las experiencias artís. ticas más importantes de las décadas anteriores a su aparición, como el refinado esteticismo inglés, la pintura de los premafaelistas, là poesía de Keats y de Poe, el pensamiento de Swedenborg, la postura parnasiana ante el arte por el arte, la nueva elaboración romántica de la música de Wagner, y el tono de sensibilidad propuesto por los decadentes. Éstos y otros influjos más formaron el caudal vasto, complejo y múltiple en el que se alza el simbolismo, que no es sino la expresión final de la última etapa romántica que se alimenta a sí misma de sustancias emanadas de sus propias raices a las que confiere un tono nuevo, aún más esotérico y subjetivo.

El movimiento, "muy individualista, muy idealista", según palabras de Remy de Gourmont, tomó formas singularmente diversas en cada uno de sus cultivadores. Reunió, eso sí, un conjunto de aspiraciones de fundamento común que no tardaron en divergir de nuevo, propagándose fe- 
cundamente aunque sin perder su genealogía. Maeterlinck se une al simbolismo en un momento en el que el movimiento se había universalizado, pero no se vuelve simbolista a partir de entonces, puesto que en realidad ya lo era. Sólo reafirma y desarrolla tendencias estéticas bien arraigadas que ya traía de su país natal, tan rico en paisajes, ambientes, literatura, creaciones plásticas, y leyendas capaces de desencadenar imágenes relacionadas con todo lo que los simbolistas buscaron. Su mundo se finca asimismo en influencias anglosajonas y en reminiscencias de viejas tradiciones flamencas. También se encuentra muy cerca de Novalis; a decir verdad, trasmina un misticismo moralista impregnado de una especie de exotismo síquico que es muy propio de los hombres del Norte.

La relación del universo intimo de Maeterlinck con la estética simbolista es muy variable, a veces directa, otras lejana, pero incluso donde es menos visible, siempre puede encontrársela como un sustrato, y no sólo en teatro y poesía, sino también en sus ensayos de divulgación cientí. fica.

Se ha dicho que Maeterlinck tenía una doble vida: la que regía la organización de sus actividades en el aspecto práctico y la que permitía que su espíritu se remontara a otros estratos en los que nacían los afluvios panteistas y ocultos que generaban el mundo de su pensamiento. De hecho su tónica vital nada tiene de pasivo ni de decadente, sino que antes bien, acusa un decidido amor a la existencia, a la acción y a las cosas concretas, totalmente opuesto a la neblina, a veces densa y pesada, otras luminosa y ligera que vela los contornos de sus expresiones. Vistas así las cosas, lo que dijo Antonio Aniante en "La double vie de Maurice Maeterlinck", tiene visos de ser cierto. Pero sólo visos, porque las apariencias se vienen abajo si examinamos esto bajo otra luz. Quien conozca la obra de Maeterlinck en sus dos aspectos: el de poeta y el de pensador, y a la vez haya tenido el cuidado de asomarse a su biografía, encontrará que no hay propiamente esa doble vida, tan frecuente en las personalidades escindidas, sino antes bien, la impresión que trasmite es la de haber sido bastante equilibrado, muy introspectivo, alerta e intituivo, orientado optimistamente hacia el trabajo y sin esos rasgos esquizoides que dicotomizan la estructura vital.

¿Cómo entonces conciliar extremos que parecen tan opuestos? En realidad no lo son tanto. No existe contradicción alguna entre la aptitud para la creación artística - que en última instancia viene a ser un producto intelectivo, y no, como románticamente se ha supuesto, de la imaginación, que al fin y al cabo es reducto intelectual- y la capacidad de 
organizar racionalmente la propia vida bajo parámetros lógicos y positivos. Maeterlinck no vivió su decadentismo ni fue bohemio jamás, como sí lo fue Rimbaud, en quien se da una conjunción perfecta entre su vida de verdadero poeta maldito y la obra que llegó a realizar en su brevísimo periodo productivo. La creación genial de Rimbaud está tanto en su vida como en su obra. Al igual que Antonin Artaud, aunque en otro sentido, es actor al mismo tiempo que autor, en tanto que Maeterlinck, como otros pensadores, poetas y artistas, es fundamentalmente autor, de tal manera que su vida activa quedó puesta al servicio de su quehacer artístico. Fue un burgués bastante realista que se realizó escribiendo y si su existencia no hubiera estado organizada por el concepto freudiano del "principio de realidad", hoy no contaríamos con los catorce volúmenes que abarcan sólo sus principales producciones.

Se ha hablado con insistencia de que su universo es vago, pasivo y en ocasiones necrólfilo, puesto que está enraizado en las filosofías fatalistas que dieron origen al naturalismo y al simbolismo. Y es precisamente aquí donde podríamos aventurar una interpretación acerca de la pretendida disparidad de sus temas. No dejará de haber quien se pregunte: ¿Es posible que el creador de una obra como Pelleas y Melisande, a la que Debussy puso música, o como La intrusa, que inspiró una soberbia pintura de Edward Munch, se haya interesado en temas tan opuestos como la vida de las hormigas o de los termes? En realidad un interés trae al otro. El naturalista que hay en Maeterlinck se preocupa del comportamiento social del hombre -o de los insectos- porque ambos tipos de comportamiento parecen desarrollarse bajo la presión de fuerzas incontrolables. Voluntad humana o instinto animal, se encuentran sometidos a influencias exteriores que influyen sobre las acciones y determinan el destino. Maeterlinck volvió su atención a los insectos, partiendo de la idea de que al estudiarlos podría encontrar algo que echara un poco de luz sobre el dilema que Gaugin planteó plásticamente en uno de sus más crípticos lienzos. ¿Qué somos, de dónde venimos y adónde vamos?

Maeterlinck participa de la sofisticada melancolía decadente sólo durante determinada fase de su vida. Es fácil percibir la evolución de su pensamiento, que va modificándose al contacto de nuevas influencias filosóficas y de un saberse poner a tono con los tiempos. De los crepúsculos tristes en los que la muerte triunfa siempte sobre el amor y donde éste no es más que un débil vahído, evoluciona hacia una creciente claridad que aunque no carece de sombras, es cada vez más cálida y consoladora. Si Pelleas y Melisande son víctimas de confusas fuerzas incontrolables, 
ya en Aglavena y Seliseta hay atisbos de voluntad que hablan de una conversión, y en El pájaro azul, claros indicios de que la felicidad existe, aunque sea inalcanzable y en cierto modo también indeseable. En forma muy semejante pensaban Mallarmé y d'Annunzio respecto a la felicidad. Este último llegó a expresar en una de sus obras que no conocía peor epíteto para un hombre que el llamarlo feliz.

Ya se ha insinuado que Maeterlinck es moralista. Dado a especular sobre el destino y la trascendencia, educado con los jesuitas y en un país de tradiciones tan rancias, se antoja que no hubiera podido menos de serlo. Su actitud moralizante también cambia con el tiempo. Al principio aparece soterrada, manifestándose en forma pasiva mediante el símbolo y la metáfora, después se activa y se expresa en términos mucho más definidos, que corresponden a una paulatina disminución del fatalismo a medida en que se va haciendo necesario proponer algo que se parezca a una fe en el futuro y en el hombre.

Los tiempos que preceden a las grandes crisis están cargados de ansiedad y de ambigüedad. El hombre prevé la catástrofe y a veces sobreviene un deseo exacerbado de apurar todo lo que la vida ofrece, a tiempo que el sentimiento contrario apunta hacia la anulación y el fatalismo. Los artistas a menudo captan este juego de tensiones y de allí la vieja idea de que el artista es profeta. Cuando pasa el periodo de vislumbrar y el desastre se hace tangible, este "alquimista del alma" que es el artista (según expresión del pintor Vlady), puede caer en una franca rebeldía, o bien, en algunos casos, su actitud subversiva cambia de tónica y llega a adaptarse filosóficamente a las nuevas circunstancias. Maeterlinck adoptó esta última postura, y de aquí que ante la proximidad de la Primera Guerra Mundial se haya inclinado mayormente por el ensayo filosófico, llegando después a hacer teatro realista de propaganda. Hubo momentos en los que se vio en él al portador de un mensaje de esperanza que en algo vino a atenuar las tinieblas del ambiente espiritual europeo. Esta circunstancia no dejó de suscitar enconadas críticas, tal vez a causa de la actitud abiertamente moralista que la inspiró. Es de justicia señalar que en todo momento su postura fue congruente con sus ideas y que si su teatro posterior a 1909, rara vez alcanza la calidad de su periodo simbolista, nunca llegó a caer en la fórmula reiterativa, ya probada, que le hubiera asegurado la perdurabilidad de un prestigio dentro de la corriente que lo hizo famoso. A propósito, la mayor parte de las obras de Maeterlinck han sido representadas varias veces, en un sinnúmero de paises. Su teatro fue apreciado no sólo por grupos de elite, sino también por los 
grandes públicos, que supuestamente muy poco tienen de místicos o de espirituales.

Su mayor aportación al teatro simbolista está referido no sólo al sugestivo esoterismo de sus argumentos, puestos al servicio de una corriente de pensamientos cuya autonomía llegó a merecer el adjetivo de "maeterlinckiano", sino sobre todo a la renovación técnica del nuevo teatro, tan vanguardista y anticonvencional, como lo fue en su momento el verso libre de Mallarmé. De aquí que Anna Balakian, en su estudio crítico sobre el movimiento simbolista, afirme que el teatro de vanguardia actual proviene directamente del simbolismo, y que para apreciar a Maeterlinck, lo mejor que puede hacer el lector o el espectador, es adentrarse en las obras de Samuel Beckett y de Ugo Betti. En cierto modo el influjo de este teatro puede extenderse hasta el cine actual, sobre todo a través de Bergman, Fellini y, señaladamente, Alain Resnais.

De hecho, una lectura cuidadosa de El pájaro azul hace pensar de inmediato en que el medium ideal para esta obra es el cine, más que el teatro. No en balde existe un filme realizado en la década de los cuarentas, cuya protagonista fue la actriz infantil más popular que ha existido: Shirley Temple, y que en el momento de escribir este ensayo haya aparecido una fastuosa producción ruso-norteamericana, dirigida por George Cukor con el guión de Maeterlinck, a la que posiblemente siga una revalorización crítica de sus piezas teatrales más notables.

Si no es la mejor de sus creaciones, El pájaro azul es la que mayormente ha resistido el paso del tiempo. Fue escrita hacia 1906 y representada poco después en Moscú y en París. En México se editó en tiraje reducido el año de 1907 y diez años después, apareció otra edición de mayor tiraje de la Editorial Cultura. A partir de su estreno, la pieza transitó varios años por los principales escenarios del mundo, pese a que no son pocas las dificultades que presenta para ser puesta en escena adecuadamente. La riqueza y variedad de imágenes que conforman los diferentes cuadros, la fluidez de los diálogos, y las amplias anotaciones con que el autor ilustra la forma como debe ambientarse cada escena, hace que el guión se lea con la facilidad de un sugestivo cuento de hadas. Un cuento de hadas rico en implicaciones filosóficas, mensajes indirectos y conceptos muy particulares que, dada la claridad con que están presentados los símbolos y la sencillez del lenguaje, ilustra de manera com. prensible varios puntos esenciales del pensamiento materlinckiano.

El tema es muy sencillo: los dos hijos de un leñador contemplan, sin asomo de envidia, la magnífica fiesta de la noche de Navidad que se desa- 
rrolla en una fastuosa residencia. En eso están cuando reciben la visita de un hada que los envía a buscar el pájaro azul, que da la felicidad a quien lo posee. Emprenden un largo viaje, acompañados de las "almas" de la luz, el fuego, el pan, el azúcar, el perro, la gata y la leche, que han adquirido características corpóreas y pueden hablar. Van al país del recuerdo, donde ven a sus abuelos y a sus hermanos muertos, luego al palacio de la noche y después a la selva. La búsqueda del pájaro azul, que parece encontrarse en todas partes, pero sólo ilusoriamente, es proseguida en el jardin de la dicha: aquí se encuentran todos los goces, desde los más nobles y delicados hasta los más groseros, incluyendo aquellos goces sencillos, como los que acompañan la vida de cada día, que nunca se perciben y que según el autor deja ver, son los más auténticos y hermosos. Llegan después al país del porvenir, donde están los niños azules que esperan el momento de su nacimiento.

Regresan de su viaje, o despiertan de su sueño, para darse cuenta de que la pobre choza en que habitan es hemosísima. Los rayos del sol iluminan las cosas en forma más viva que antes, todo parece haber adquirido mayor intensidad: los colores, los sonidos, el contorno de los objetos. E1 pájaro azul está allí. Es la pequeña tórtola de cuyo plumaje no habian tomado conciencia, aunque siempre los había acompañado desde su jaula. A instancias de una vieja vecina que es la encarnación diurna del hada, el niño lo da a una muchachita enferma. La niña recupera la salud, pero minutos después el pájaro huye.

La alegoría es muy clara. El pájaro azul es la felicidad perfecta, que se identifica en cierta forma con el conocimiento de todas las cosas. Es necesario buscarlo para ser felices, aun y cuando no pueda vivir entre los hombres sin que cambie el color de su plumaje. Parece encontrarse en todas partes, pero la felicidad humana no depende de su posesión, sino de la disposición interior que acompaña a su búsqueda, actuando como la luz de un diamante. Esta luz es capaz de revelar la esencia de los goces naturales y sencillos que son los únicos capaces de proporcionar dicha genuina.

A lo largo de la trama, se insertan varios de los conceptos que con más insistencia preocupan al autor.

Así, el país del pasado representa la vigencia de las imágenes que alberga Ia memoria. Ésta es capaz de disipar la densa niebla que oculta los seres, las cosas y las situaciones, permitiendo que vuelvan a la vida, en tal forma que, mientras exista la posibilidad de evocar, existe también la realidad de lo evocado. Solamente aquello en lo que jamás piensa 
está realmente muerto, lo demás duerme. Al situar en el mismo plano de la representación a los personajes vivos y a los evocados, el autor habla de la realidad presente y activa de las imágenes pasadas en lo que se alía con el descubrimiento de la presencia dinámica del inconsciente. Los abuelos y los hermanos muertos a quienes los protagonistas visitan, viven en la medida en que se les recuerda, como reviven asimismo otras experiencias al pasar al plano consciente a través de la memoria.

La escena del cementerio toca el aspecto de la supervivencia a otro nivel. No se trata aquí del fenómeno de la muerte, sobre el que el autor especula espléndidamente en $L a$ intrusa y en un ensayo en prosa, sino de la condición sustancial de lo que ya no vive. Como buen teósofo, Maeterlinck se inclinaba por un pantésmo muy acorde con la metafísica simbolista. De hecho, la trasformación del cementerio en un hermosí. simo jardín nupcial es un símbolo de amorosa unión entre la vida y la muerte. Ésta no existe como negación de la vida, sino como resultado de una trasformación en otra forma particular de ser.

El país del futuro cierra el ciclo sobre las postrimerías y los orígenes. Por su arquitectura, pródiga en clásicas construcciones de mármol o alabastro, y por la atmósfera azul que lo envuelve, también evoca la imagen de un gran cementerio. Allí habitan los niños que han de venir al mundo a una señal del tiempo. Todos traen consigo la marca de duración del periodo que habrán de deambular por la tierra, y asimismo los descubrimientos, objetos o símbolos de los trabajos que van a realizar en su paso por ella. Están los artistas, los científicos, los inventores, también los grandes reformadores y los que serán capaces de producir catástrofes y convulsiones que cambiarán la faz del mundo. Todo lo que harán los hombres en el curso de los siglos, se encuentra ya previsto.

El país es azul, el color preferido de los simbolistas, identificado con el agua, origen de la vida y también con el azur de Mallarmé y Darío, que combina los significados de azul e infinito.

El tono moralista del cuento aparece desde el principio y se reafirma en las últimas escenas. Los bienes materiales, de los que gozan los niños ricos en la fiesta navideña, aparecen trasformados en "groseras dichas" en el país de los goces, que por cierto no deja de recordar en alguna forma las rondas de placeres de El jardin de las delicias de Jerónimo Bosch. Las diferencias entre pobres y ricos son insinuadas varias veces. Sin asomo de desdén ni tono crítico obvio, el autor pone en evidencia la futileza de todos aquellos "bienes" que la riqueza trae consigo, situando a la felicidad del lado de los humildes, seguramente porque Maeterlinck 
siempre disfrutó de una bien saneada fortuna. Esto le permite expresar por boca del protagonista, quien es pobre, pero no codicioso, que "los que no tienen pueden mirar a los otros". Son tan burdos los bienes materiales que a fin de cuentas vale más verlos que poseerlos. Aquí el asceta sale al encuentro del estético, sin que logre proponer realmente una estética ascética, como haría Mondrian poco tiempo después.

En los albores del siglo, Maurice Maeterlinck inició una serie de interpretaciones del mundo animal y cósmico que forman un ciclo concluido treinta años después. Entre ellas están: La vida de las abejas (1901), El templo sumergido (1902), La inteligencia de las flores (1907), La vida de los termes (1926), La vida del espacio (1929), y La vida de las hormigas (1930).

De todas estas obras, la trilogía sobre los insectos sociales es la que conserva mayor vigencia, tanto por el interés que el tema suscita y por la forma en que está tratado, como porque representa un complemento de las ideas fundamentales que el autor se ha planteado en torno al enigma del destino y la trascendencia.

Vastos conocimientos bibliográficos de orden científico e histórico apuntalan más de veinte años de experiencia en la apicultura y una serie de experimentos sistematizados con otros insectos. Como norma básica existe la proposición de "no engalanar la verdad, ni sustituir una maravilla real por una maravilla complaciente o imaginaria". La finalidad es presentar los hechos tal y como han sido observados, confrontándolos con opiniones de reconocidos especialistas. La labor de interpretación, sin la que nos encontraríamos simplemente frente a una documentada relación, deriva de todo un sistema ideológico cuyas raíces, como ya se anotó, se encuentran en las corrientes naturalistas. $\mathrm{El}$ contenido está expresado en una prosa ágil y elegante, evocadora del poeta que existe tras de quien, por el momento, se dedica a estudiar los ires y venires coordinados de esos pequeños organismos.

Ninguno de los tres ensayos llega a alcanzar los requerimientos metodológicos inherentes a la entomología cientifica contemporánea. El autor es un poeta que escribe sobre los insectos y no un científico que poetiza sobre ellos. Aun así, el manejo de los datos recabados mediante la observación directa y la cuidadosa selección de las fuentes bibliográficas, acusan un método riguroso y una mentalidad familiarizada con las disciplinas cientificas. Además, los textos están salpicados de observaciones muy finas y de brillantes descripciones en las que la pasión por el tema nunca llega a empañar la credibilidad de los hechos. 
De las tres obras, La vida de las abejas es la que se fundamenta mayormente en la observación directa. Deriva de un temprano encuentro que tuvo lugar en un pueblo de la Flandes Zeelandesa cuando el autor era aún muy joven: "...Recuerdo el primer colmenar que vi y en el que aprendí a querer a las abejas... en aquel punto, como donde quiera que se coloquen, las abejas habían dado a las flores, al silencio, a la dulzura del aire, a los rayos del sol, una significación nueva..."

Maeterlinck estudia las diversas especies de abejas mostrando sus afinidades y diferencias, como también las que presentan con otros insectos. Sin embargo, el objeto primordial de su interés es la Apiens Melifica, o sea la abeja doméstica, que ocupa uno de los estratos más altos dentro 
a la que todos conocemos (fuera de la colmena); es inmaculada, imponderable, parece verdaderamente el alma de la miel,..."

En la maravilla urbana creada por estos seres altamente cívicos tendríamos el mejor modelo para la más exigente de las utopías, a no ser por ciertos hechos que Maeterlinck califica de crueles y despiadados, como la lucha de la joven reina con sus rivales, que conduce a la muerte por decapitación de todas ellas, o como la prisión a que se ve sometida una reina intrusa. La narración de tales avatares "políticos" está realizada con esa capacidad de asombro tan necesaria para provocar interés y fas. cinación.

Pero es en "el vuelo nupcial" donde el autor descubre la posibilidad de irrumpir poéticamente a través de algunas de sus imágenes más perseguidas, que encuentran ideal correspondencia en el trozo literario más bello que hasta hoy se ha escrito en torno a las costumbres de estos insectos. "Prodigiosas bodas, las más fantásticas que podamos imaginar, azuladas y trágicas... solitarias e infinitas". Bodas azules, trágicas y fantásticas, llevadas a cabo en el espacio. Imposible no ver en ellas una imagen prototípicamente simbolista, sobre todo si se tiene en cuenta que el macho muere al consumarlas.

Hay muchas cosas que quedan en el misterio. El hombre, poderoso interventor que ha llegado a someter la colmena, no alcanza a comprender todo lo que en ella ocurre. Pero se pregunta Maeterlinck: cacaso un ser que observara a los humanos desde otro plano, tal y como nosotros observamos a las abejas, llegaría a comprender el significado de sus acciones? Esto da lugar a uno de los párrafos más singulares de toda la obra, en donde asistimos al espectáculo que supuestamente presentariamos a quienes durante siglos nos hubiera estado observando.

Los termes $u$ hormigas blancas son en buena medida la antitesis de las abejas, motivo por el que los dos ensayos son como el día y la noche, el alba y el crepúsculo, el cielo y el infierno. Si en la colmena todo es luz, estío y miel, en las mazmorras de los termes reina la opresión bajo un ambiente de sepulcro.

Dado que estos insectos, que también se caracterizan por sus instintos sociales, viven únicamente en regiones tropicales o subtropicales, fueron contadas las veces que el autor tuvo la oportunidad de enfrentarse direc. tamente a ellos. La obra, por lo tanto, se monta en las fuentes de información proporcionadas por los entomólogos especializados en este tema, a las que se suman interesantes observaciones recogidas por un gran número de viajeros que pudieron observar desde puntos cercanos a estos 
peculiares seres, casi ciegos, pero provistos de un notable desarrollo instintivo que se despliega, sobre todo, en la inexpugnabilidad de la comejenera, en las defensas que crean para poder resistir los embates de otros animales y en las ocultas iniciativas que despliegan para procurarse el sustento, desarrollando una actividad devastadora.

La comejenera es descrita como un recinto diabólico que se antoja digno de haber servido de inspiración a Piranesi y Magnasco. Maeterlinck habla de edificaciones pródigas en columnas, bóvedas de estalactitas, arbotantes y pináculos "evocadores de catedrales carcomidas por los siglos ... castillos en ruinas o ciudades fantasmagóricas..."

Similarmente a lo que ocurre con las abejas, la vida de los termes se basa en una estricta organización económica en la que la división del trabajo determina las características físicas de cada grupo de organismos, verdaderos instrumentos vivientes cuyos órganos han tomado formas de herramienta. A través de páginas alucinantes, el autor nos informa acerca de la coprofagia practicada por estos animales saturnianos que han hecho de las tinieblas su aposento y de la destrucción su medio de subsistencia. Por momentos nos preguntamos si lo que narra no estará sacado de algún terrible infierno flamenco, como aquellos en que es tan pródiga la pintura de los Países Bajos de los siglos xv y xvi. Pero no es así, fiel a su máxima, Maeterlinck no adorna la realidad y ni siquiera vale decir que la recrea, sino que respetándola hasta en sus más insignificantes elementos, la convierte en otro tipo de realidad, propia del arte.

La vida sexual de los termes, trágica y grotesca a la vez, nos hace conocer a una reina aparejada con un príncipe consorte servil y efímero, cuya única misión es fecundarla continuamente durante su etapa fértil. Para procrear, el vientre de la reina se convierte en una enorme matriz, vorazmente alimentada. La naturaleza nos presenta en este caso, como en muchos otros (la araña, por ejemplo), un modelo de femme fatal aún más terrible que las propias Salomés y Herodias de la literatura y la plástica simbolista.

La obra termina con una amplia disertación sobre el instinto y la inteligencia, que en sí constituye un ensayo independiente en el que Maeterlinck toma de nuevo algunos puntos que han aparecido ya en La vida de las abejas. Sugiriendo una posibilidad de explicación a los misterios de la vida y el destino, utiliza el término de Anima mundi para abarcar, ilimitadamente, todas aquellas cuestiones cuya solución es un misterio.

Al momento de escribir La vida de las abejas, Maeterlinck era un 
hombre cercano a los cuarenta años que afirmaba contentarse con el valor limitado y perentorio de la existencia material, sin pedir nada más. Veinticuatro años después, varias estructuras que habían prevalecido por siglos cambiaron por completo. Trastocados los valores, hasta la noción del tiempo adquirió para el autor otra dimensión. Como Una. muno, encuentra que la situación del hombre es trágica: "quizá su único enemigo sea la materia". La felicidad sólo sería posible en una vida del todo espiritual, "de este o del otro lado de la tumba ... porque todo lo que está unido a la materia es cambiante, precario y perecedero". Alienta en estas palabras una esperanza, o mejor dicho, una necesidad de supervivencia y de felicidad, que lo hacen no sólo desear, sino afirmar que "teóricamente tal vida es posible".

En 1930 Maeterlinck completó sus estudios acerca de los insectos sociales con La vida de las hormigas. Hasta entonces este insecto no le había suscitado demasiada simpatía, pensaba que la hormiga era demasiado conocida y no muy agradable. Pero al sistematizar sus conocimientos, confrontándolos con observaciones directas, cambió de parecer sucediéndole lo que siempre acontece cuando una mente curiosa aborda un tema hacia el que siente cierta prevención. El acercamiento inicial trae consigo un incremento en la curiosidad que necesita satisfacerse a toda costa, en tal forma que el interés llega a convertirse en pasión. Así, en el libro sobre las hormigas encontramos la misma admiración respetuosa y la misma postura ecuánime, pero no exenta de entusiasmo, que tonifica las dos obras anteriores. Además, ahora existe una base más amplia sobre la que establecer analogías y diferencias, de lo que resulta que en este ensayo vuelven a considerarse puntos importantes ya tratados en los otros dos, vistos ahora bajo una nueva luz.

El concepto acerca de un espíritu rector se ha afinado tomando otros matices, dado lo cual algunas preguntas que hasta ahora habian dado lugar a explicaciones excesivamente vagas, encuentran respuestas reno. vadas que se sitúan ya en el terreno de la hipótesis.

Surge la idea del organismo colectivo único -en este caso el hormiguero- que debe ser considerado como un individuo cuyas células, al contrario de lo que ocurre con las de nuestro cuerpo, se encuentran disociadas y exteriorizadas sin dejar de permanecer sometidas a la misma ley central.

Esta explicación no es la única. "También es posible que se descubra cualquier dia una red de relaciones electromagnéticas, etéreas o síquicas de las cuales apenas si tenemos una muy vaga noción." Aquí reaparece 
el teósofo, interesado en los fenómenos extrasensoriales que, de vivir hoy en día, sin duda sería uno de los más notables investigadores dentro del campo de la moderna parasicología.

Entre las hormigas, el amor tiene casi siempre la misma cara de la muerte. Su vuelo nupcial es menos fastuoso que el de las abejas, "como corresponde a la humilde librea de estos insectos, recuerda las modestas bodas campesinas". Pero lo terrible es que en estas nupcias proletarias no sobrevive ni uno solo de los machos, y de cada mil desposadas sólo un número ínfimo alcanza a cumplir los destinos de su especie. Es por esto que la mayor parte de las hormigas son célibes, o mejor dicho, neutras, por más que estemos habituados a considerarlas $-\mathrm{y}$ no sin razón- como hembras, puesto que varias de sus virtudes son típicamente femeninas. El ethos de la hormiga es, desde luego, el trabajo, y esta idea la encontramos desde Esopo. Si un ser humano trabajara "como una hormiga", seguramente sería acreedor a la gloria celestial tal y como se propone en las teorias reformistas sobre la justificación por las obras.

Nuevamente la imagen de la hembra fecundada, "cuyas alas caen a sus pies cuando termina la fiesta", es evocadora de aquel otro universo que años atrás pobló de blancas figuras de desposadas o de princesas ahogadas por sus propios cabellos, el rico arsenal de la iconografía simbolista.

Con esta tentativa de presentar una aproximación a la lectura de dos de los temas mas frecuentemente tratados por Maurice Maeterlinck; el que revela su asociación al pensamiento simbolista a través del teatro y el que lo aproxima a la investigación naturalista, sólo hemos querido señalar que ambos intereses se encuentran en su obra íntimamente entrelazados. Amor-muerte, moral-trabajo, destino-postrimerías son binomios que al combinarse unos con otros convergen a una misma meta: el sondeo de un misterio cuyo descubrimiento no es realmente buscado, puesto que tampoco es posible ni deseable. 